\title{
B cells characterization in ADA2 Deficiency patients
}

\author{
F Schena ${ }^{1 *}$, S Volpi ${ }^{1}$, R Caorsi ${ }^{1}$, C Pastorino ${ }^{1}$, F Penco ${ }^{1}$, F Kalli ${ }^{2}$, A Omenetti ${ }^{1}$, S Chiesa ${ }^{1}$, A Bertoni ${ }^{1}$, P Picco ${ }^{1}$,

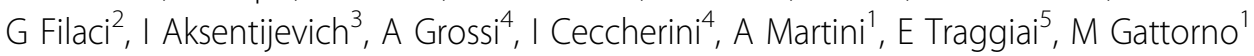 \\ From 8th International Congress of Familial Mediterranean Fever and Systemic Autoinflammatory Diseases \\ Dresden, Germany. 30 September - 3 October 2015
}

\section{Introduction}

ADA2 deficiency, a recently described disease, is characterized by systemic vasculopathy and episodes of strokes. The defect is due to a loss of function mutation of CECR1 gene, codifying for Adenosine Deaminase 2 protein. This protein regulates the catabolism of extracellular adenosine, which we have recently shown is an important regulator of Class Switch Recombination in B lymphocytes. Accordingly DADA2 patients can present hypogammaglobulinemia.

\section{Objectives}

Therefore we decided to characterize peripheral B and $T$ lymphocytes of DADA patients to directly address if ADA2 mutation affects B-cell function and in particular we focused on $\mathrm{B}$ cell- $\mathrm{T}$ cell interaction.

\section{Patients and methods}

3 patients carrying mutations in CECR1 were examined. They showed clinical history with livedo reticularis, fever, vasculitis and neurological symptoms. Two patients presented hypogammaglobulinemia requiring intravenous immunoglobulin replacement therapy. We analyzed peripheral $\mathrm{B}$ and $\mathrm{T}$ cell phenotype by flow cytometry, in vitro B-cell proliferation and differentiation to Immunoglobulin secreting cells in response to $\mathrm{CpG}$ and $\mathrm{T}$ cell help.

\section{Results}

Flow cytometer analysis showed a reduction of total $B$ cells compared with age matched controls. Intriguingly a decrease in the percentage of memory B cell compartment $(\mathrm{CD} 19+\mathrm{CD} 27+)$ was observed. Moreover we noted that the rate of $B$ cells proliferation and differentiation to Immunoglobulin Secreting Cells of DADA2 patients with autologous $T$ cell help are impaired. In fact in vitro IgM, IgG and IgA secretion is significantly reduced with

${ }^{1}$ Gaslini Institute, Second Pediatric division, Genoa, Italy

Full list of author information is available at the end of the article respect to HD B lymphocytes in presence of mutated $\mathrm{CD} 4$ helper T cells.

\section{Conclusions}

Our findings suggest that ADA2 defect could lead to a defect in $B$ cell function and to a reduced $T$ cell dependent $B$ cell response.

\section{Authors' details}

${ }^{1}$ Gaslini Institute, Second Pediatric division, Genoa, Italy. ${ }^{2}$ University of Genoa, CEBR, Genova, Italy. ${ }^{3}$ National Institute of Health, National Human Genome Research Institute „Bethesda, USA. ${ }^{4}$ Gaslini Istitute, Medical Genetics, Genova, Italy. ${ }^{5}$ Novartis Institute for Research in Biomedicine, Basel, Switzerland.

Published: 28 September 2015

doi:10.1186/1546-0096-13-S1-P65

Cite this article as: Schena et al:: B cells characterization in ADA2

Deficiency patients. Pediatric Rheumatology 2015 13(Suppl 1):P65.
Submit your next manuscript to BioMed Central and take full advantage of:

- Convenient online submission

- Thorough peer review

- No space constraints or color figure charges

- Immediate publication on acceptance

- Inclusion in PubMed, CAS, Scopus and Google Scholar

- Research which is freely available for redistribution
() Biomed Central
C Biomed Central

C 2015 Schena et al. This is an Open Access article distributed under the terms of the Creative Commons Attribution License (http:// creativecommons.org/licenses/by/4.0), which permits unrestricted use, distribution, and reproduction in any medium, provided the original work is properly cited. The Creative Commons Public Domain Dedication waiver (http://creativecommons.org/publicdomain/ zero/1.0/) applies to the data made available in this article, unless otherwise stated. 